FACTA UNIVERSITATIS

Series: Physical Education and Sport, Vol. 17, No 2, 2019, pp. 385 - 395

https://doi.org/10.22190/FUPES190413034M

Research article

\title{
THE EFFECTS OF AN ARTISTIC GYMNASTICS PROGRAM ON THE PHYSICAL FITNESS OF ADOLESCENTS
}

\author{
UDC 796.41.015.132:371.214-053.6
}

\section{Marija Miletici ${ }^{1,2}$, Hadži Saša Ilić ${ }^{3}$, Miljan Jeremićc ${ }^{4}$ Milutin Parlić ${ }^{1}$, Igor Ilić ${ }^{3}$, Hadži Miloš Vidaković ${ }^{3}$}

${ }^{1}$ Faculty of Sport and Physical Education, University of Niš, Niš, Serbia

${ }^{2}$ Technical High School, Knjaževac, Serbia

${ }^{3}$ Faculty of Sport and Physical Education in Leposavić, University of Priština, Leposavić, Serbia

${ }^{4}$ Knjaževac Gymnasium, Knjaževac, Serbia

\begin{abstract}
The aim of the research is to determine the effects of an artistic gymnastics program on the physical fitness of adolescents. The sample of participants consisted of 28 participants, males, aged 14 years \pm 6 months, seventh graders of "Bubanjski Heroji" elementary school in Niš. The sample was divided into two subgroups. The experimental group (EG) consisted of 14 participants who, during the experimental period, realized the program of artistic gymnastics during the main phase of a physical education class, ten weeks over two classes of 45 minutes. The control group (CG) consisted of 14 participants who during the experimental period realized the program contents of regular physical education in the main phase of physical education. The sample of motorized measuring instruments consisted of three variables of explosive power (standing long jump, standing triple jump and vertical jump) and three variants of the sprint run (20m spring with a flying start, $30 \mathrm{~m}$ sprint with a flying start and $50 \mathrm{~m}$ sprint with a flying start). The program "Statistica" 8.0 for Windows was used to calculate the basic statistics, canonical discriminatory analysis and multivariate analysis of covariates. The results of the study showed that there are statistically significant effects of the use of artistic gymnastics exercises in the main part of the physical education course on the physical fitness of the adolescent of the EG at the end of the experimental period.
\end{abstract}

Key words: Artistic gymnastics, Teaching, Physical fitness, Adolescents

Received April 13, 2019/ Accepted October 02, 2019

Corresponding author: Marija Miletić

Faculty of Sport and Physical Education, University of Niš, Niš, Čarnojevića 10a, 18000 Niš, Serbia

Phone: +381 $18510900 •$ E-mail: marijamacamiletic@gmail.com 


\section{INTRODUCTION}

A successful routine in artistic gymnastics consists of the most complex coordination elements and their successful execution (Veličković et al., 2011). In exercises, on the spring board and the floor, the insistence is on the proper keeping of the body and beautifully shaped movements, which is in the domain of aesthetic education as segments of educational tasks of pedagogical practice (Broomfied, 2011).

Muscular fitness implies physical activation of a man in order to achieve positive effects on muscular strength and endurance, as well as on mineral bone density (Jorgić, Pantelić, Milanović, \& Kostić, 2011).

Physical fitness implies fitness components that are defined as a set of innate and acquired abilities that enable successful performance of motor activities. A number of researchers studied the motor space of anthropological status (Zatsiorsky, 1975; Kurelić, Momirović, Stojanović, Šturm, Radojević, \& Viskić-Štalec, 1975; Findak, 1999; Malacko, 2002; Ortega, Ruiz, Castillo, \& Sjostrom, 2008), so in this domain there is a greater number of definitions of motor skills. Motor gymnastics are those aspects of motor activity that occur in moving structures, which can be described by the same parametric system, which can be measured by an equal set of measures, and in which analogous physiological, biochemical, cognitive and conical mechanisms occur. Although these relationships are realized most often at the same time, it is possible to force the development of certain segments of anthropological status, the appropriate choice and schedule of motor exercises, using adequate methods and an appropriate volume of load. Motor sports are the basis for each learning of motor tasks of some particular technique, so it can be considered to represent the baseline in the total area of anthropological status (Pantelić et al., 2014).

The period of adolescence can be observed functionally when viewed through maturation that begins with changes in the neuroendocrine system, and the appearance of secondary sex characteristics and initial reproductive capacity, and ends with the complete protection of reproductive organs. Psychologically, an adolescent is a person in the transition period between behavior typical of a child and behavior typical of adults, and from the sociological point of view they are in the period of guidance and choosing a future profession, training for that profession and the period of increased independence in relation to their parents (Vranješević, 2001). Authors dealing with adolescence talk about three periods: early adolescence (ages 12 to 15), middle adolescence (ages 15 to 17) and adolescence (after 17 years), emphasizing that each division is arbitrary (Kimmel \& Veiner, 1995).

The goals and tasks of teaching physical education, envisaged in the curriculum, are in the function of developing the anthropological characteristics of students, primarily developing the motor and functional abilities of students, coordinating elements of the movement and development of creative activities in the direction of sports and technical achievements (Krsmanović, 2000; Višnjić, 2006). Research shows that the effects of the achieved changes in the teaching process can only be expected under the condition of establishing optimal relationships in the development of appropriate abilities, qualities and motor skills (Ilić, 1991; Foks, 1994; Ilić, Popović Ilić, Ilić, Petković, \& Mekić, 2014).

The aim of the research is to determine the effects of artistic gymnastics on the physical fitness of adolescents. 
METHODS

\section{The sample of participants}

The sample of participants consisted of 28 participants, aged 14 years \pm 6 months, seventh grade students of the primary school "Bubanjski Heroji" in Niš. The sample was divided into two subgroups. The experimental subgroup (EG) was made up of 14 males who during the experimental period realized the model of an artistic gymnastics program (floor and vaulting horse) in the main phase of the physical education classes, for 16 weeks in two classes of 45 minutes. The control group (CG) consisted of 14 participants who during the experimental period during the main phase of physical education realized the program contents of regular physical education, 16 weeks in two classes for 45 minutes ("Official Gazette of the Republic of Serbia - Educational Gazette", no. 6/2009, $3 / 2011$ - other regulations and 8/2013, 11/2016 and 12/2018, 217-225).

\section{Instruments}

The sample of measuring instruments for fitness assessment included a set of three sprint run tests: $20 \mathrm{~m}$ sprint with a flying start (M20VS in s), 30m sprint with a flying start (M30VS in s) and 50m sprint with a flying start (M50VS in s) and explosive power: the standing long jump (MSLJ in $\mathrm{cm}$ ), standing triple jump (MTJOS in $\mathrm{cm}$ ), vertical jump (MVJ in $\mathrm{cm}$ ). All the variables for speed estimation were measured by the Witty wireless training system - photo cells and timer (Microgate, Italy). The applied set of motor variables was taken from the research of Kurelić, Momirović, Stojanović, Šturma, \& Viskić-Štalec (1975).

\section{Procedures}

The experimental factor during the physical education classes was the program of sports gymnastics, i.e., the vaulting exercise on the floor and on a vaulting horse, in the main part of the class, for seventh grade elementary school students. The experimental group of participants carried out an experimental program of sports gymnastics, twice a week, during an experimental period that lasted 16 weeks (a total of 32 hours). For each exercise on the floor and vaulting during the experiment, after a demonstration by a professor of physical education, the participants were trained to guard and assist other group members and personally perform the exercise. Each exercise on the floor and vault was firstly methodologically processed, and the next time, it was practiced through different situations. CG realized the contents for regular seventh grade physical education classes according to the plan and program of teaching physical education for elementary education of the Ministry of Education (Official Gazette of the Republic of Serbia, 2017).

\section{Data analysis}

The obtained results were processed with the appropriate statistical program SPSS and Statistics 8.0. The parameters of descriptive statistics, canonical discriminatory analysis and multivariate covariance analysis were calculated. 


\section{RESULTS}

Table 1 Significance of isolated discriminatory function in Physical fitness in the EG

\begin{tabular}{ccccccc}
\hline Disc. Func. Eigenvalue & $\begin{array}{c}\text { Canonical } \\
\mathrm{R}(\mathrm{CR})\end{array}$ & $\begin{array}{c}\text { Wilks' } \\
\text { Lambda }\end{array}$ & Chi-Sqr. $\left(\chi^{2}\right)$ & df & P-Level \\
\hline 1 & 2.546 & 0.79 & .261 & 112.37 & 14 & $.000^{* *}$ \\
\hline
\end{tabular}

Legend: squared coefficient of discrimination (Eugenvalue), canonical correlation coefficients (Canonical $\mathrm{R})$, values of Bartlett's test (Wilks' Lambda), the size of the square of the test $\operatorname{Chi}$-Sqr $\left(\chi^{2}\right)$, the degrees of freedom (df) and the significance level of the coefficient of determination (P-Level)

In table 1 there is one discriminatory high intensity function $(\mathrm{CR}=79 \%)$ which shows the correlation of the data set based on which a discriminatory analysis of the obtained results was carried out. The results of the discriminative strength of motor variables given by Wilks'Lambda value of .261 show that the differences between the initial and final measurements in the space of physical fitness variables in the EG are statistically significant (P-Level $=.000 * *$ ), since the size of the square test has a high value (Chi-Sqr $(\chi 2)=112.37)$.

Table 2 The factor structure of the isolated discriminant function in physical fitness variables in the EG

\begin{tabular}{lr}
\hline Physical fitness variables & Root 1 \\
\hline M20FOFS & -0.468 \\
M30FOFS & -0.452 \\
M50FOFS & -0.429 \\
MSLJ & 0.745 \\
MTJOS & 0.677 \\
MVJ & 0.661 \\
\hline
\end{tabular}

Legend: 20m sprint with a flying start (M20FOFS), 30m sprint with a flying start (M30FOFS) and 50m sprint with a flying start (M50FOFS), the standing long jump (MSLJ), standing triple jump (MTJOS), vertical jump (MVJ)

Table 2 shows the structure of the discriminant function of the participation of the variables of the Physical fitness of the EG in the formation of significant discriminatory functions. The shown centroid groups in the Root 1 column represent the arithmetic means of the initial and final measurement of the Physical fitness variables.

The obtained results indicate that the greatest contribution to the discriminant function of the canonical correlation coefficient R (CR-0.76) is made by the explosive power variables of the standing long jump (MSLJ 0.745), the standing triple jump (MTJOS 0.677) and the vertical jump (MVJ 0.661), 20m sprint with a flying start (M20FOFS -0.468), 30m sprint with a flying start (M30FOFS -0.452) and 50m sprint with a flying start (M50FOFS -0.429) have a high contribution to the discriminant function of the canonical correlation coefficient.

The obtained results of the discriminant analysis in the final in relation to the initial measurement in the EG of participants indicate that under the influence of the implementation of the program of artistic gymnastics in the main part of the class of physical education, there were statistically significant changes in the variables of the physical fitness of the participants. 
Table 3 Significance of the isolated discriminant function in physical fitness with CG

\begin{tabular}{ccccccc}
\hline Disc. Func. Eigenvalue & $\begin{array}{c}\text { Canonical } \\
\mathrm{R}(\mathrm{CR})\end{array}$ & $\begin{array}{c}\text { Wilks' } \\
\text { Lambda }\end{array}$ & Chi-Sqr. $\left(\chi^{2}\right)$ & df & P-Level \\
\hline 1 & 0.462 & .31 & .594 & 12.38 & 14 & .309 \\
\hline
\end{tabular}

Legend: squared coefficient of discrimination (Eugenvalue), canonical correlation coefficients (Canonical $\mathrm{R})$, values of Bartlett's test (Wilks' Lambda), the size of the square of the test $\operatorname{Chi}-\operatorname{Sqr}\left(\chi^{2}\right)$, the degrees of freedom (df) and the significance level of the coefficient of determination (P-Level)

The results shown in Table 3 indicate that a low-intensity discriminant function $(\mathrm{CR}=$ $31 \%$ ) was obtained indicating the correlation of the data set on the basis of which the discriminant analysis was carried out. The results of the discriminant intensity of Wilks'Lambda with a value of .594 indicates that the parameters of the difference between the initial and final measurements in the area of physical fitness variables in the CG are statistically low and insignificant $(\mathrm{P}$-Level $=.309)$, since the size of the Chi square test has a low value $\left(\right.$ Chi-Sqr $\left.\left(\chi^{2}\right)=12.38\right)$.

Table 4 The factor structure of the isolated discriminant function in physical fitness variables in the $\mathrm{CG}$

\begin{tabular}{lr}
\hline Physical fitness variables & Root 1 \\
\hline M20FOFS & -0.199 \\
M30FOFS & -0.190 \\
M50FOFS & -0.172 \\
MSLJ & 0.264 \\
MTJOS & 0.260 \\
MVJ & 0.255 \\
\hline
\end{tabular}

Legend: $20 \mathrm{~m}$ sprint with a flying start (M20FOFS), 30m sprint with a flying start (M30FOFS) and 50m sprint with a flying start (M50FOFS), the standing long jump (MSLJ), standing triple jump (MTJOS), vertical jump (MVJ)

Table 4 shows the structure of the discriminant function of the participation of variables in the motor control of the $\mathrm{CG}$ in the formation of significant discriminant functions. The shown centroid groups in the Root 1 column represent the arithmetic means of the initial and final measurement of the physical fitness variables. The obtained results indicate that the contribution to the discriminant function of the canonical correlation coefficient R (CR .31) yields low and insignificant coefficients of the sprinter speed variables and the explosive strength of the participants.

The obtained results of the discriminant analysis in the final versus the initial measurement in the $\mathrm{CG}$ of the participants indicate that under the influence of the realization of the program contents of regular physical education classes there were no statistically significant changes in the variables of the physical fitness of the participants. 
Table 5 The multivariate analysis of covariance in physical fitness between the EG and $\mathrm{CG}$ at the final measurement

\begin{tabular}{|c|c|c|c|}
\hline & Wilks' Lambda & Rao's R & $\mathrm{Q}$ \\
\hline & .150 & 8.28 & .000 \\
\hline
\end{tabular}

Table 5 shows the results of the multivariate analysis of covariance between the experimental and CG on the final measurement, which indicates that there is a statistically significant intergroup difference in physical fitness variables since Wilks' Lambda is .150, which by Ra's F-approximation of 8.28 gives a significance of the difference at the level of $\mathrm{Q}=.000$. Therefore, in the applied system of the dimensions of the physical fitness of the participants, statistically significant differences were determined.

Differences in physical fitness parameters (dimensions of sprint speed and explosive power) were created under the influence of the program of artistic gymnastics as a methodical form of work in the main part of the physical education class in the EG of participants.

Table 6 The univariate analysis of covariance in physical fitness variables between the EG and $\mathrm{CG}$ at the final measurement

\begin{tabular}{lcccc}
\hline Physical fitness variables & Means (E) & Means (K) & F-relation & Q \\
\hline M20FOFS & 3.88 & 4.37 & 6.65 & .000 \\
M30FOFS & 5.26 & 5.66 & 4.78 & .002 \\
M50FOFS & 8.29 & 8.93 & 5.07 & .001 \\
MSLJ & 198.78 & 184.45 & 5.38 & .000 \\
MTRSM & 610.43 & 530.83 & 4.65 & .002 \\
MVJ & 33.28 & 27.37 & 3.10 & .004 \\
\hline Legend: arithmetic mean of the EG [Mean (E), arithmetic mean of the CG (Mean (K)], \\
\multicolumn{4}{c}{ F-test value (F-ratio) and level of significance (Q) }
\end{tabular}

Table 6 shows the univariate variance analysis of physical fitness variables by comparing the results of the arithmetic mean of the EG and $\mathrm{CG}$ at the final measurement. Based on the coefficients of the F-ratio and their significance (P-Level), it can be concluded that a statistically significant difference in the level of physical fitness dimensions between the EG and $\mathrm{CG}$ was determined for the following variants of physical fitness: $20 \mathrm{~m}$ sprint with a flying start (M20FOFS .000), 30m sprint with a flying start (M30FOFS .002), 50m sprint with a flying start (M50FOFS .001), the standing long jump (MSLJ .000), the standing triple jump (MTJOS .002) and the vertical jump (MVJ .004).

It can be assumed that these changes were the result of the correct methodological design of the experimental teaching model of the program of artistic gymnastics in the process of planning and programming, distribution and control of the dosage of applied loads, as well as increasing the intensification of teaching work in accordance with the individual needs of the EG. 


\section{DISCUSSION}

The obtained results of the discriminatory analysis in the final versus the initial measurement in the EG of participants indicate that under the influence of the realization of the teaching model of the artistic gymnastics program in the main part of the physical education time, there were statistically significant changes in the variables of the physical fitness of the participants.

It can be assumed that these changes were the result of the correct methodological design of the experimental teaching model of the program of artistic gymnastics in the process of planning and programming, distribution and control of the dosage of applied loads, as well as increasing the intensification of teaching work in accordance with the individual needs of the EG.

The obtained results of the discriminatory analysis in the final, versus the initial measurement in the $\mathrm{CG}$ of the participants indicate that under the influence of the realization of the program contents of the regular teaching of physical education there were no statistically significant changes in the variables of the physical fitness of the participants.

Some studies have found that the efficiency of the realization of program contents of regular teaching is not at a satisfactory level and that positive effects can be achieved with a variety of contents from the natural forms of movement, athletics, artistic gymnastics and sports games as well as by exercising additional exercises (Krsmanović, 2000; Zrnzević, 2007).

The results of the canonical discriminant analysis in the EG of participants showed that at the end of the experiment, the application of the program of artistic gymnastics resulted in statistically significant adaptive changes in the dimensions of the physical fitness of the adolescents of the EG. The applied methods and means of the teaching model of the sports exercise gymnastics program with EGs increased the ability of faster and more complete activation of motor units with a high level of loading, which enabled increased agonist muscle activity and increased strength of the whole body. A large number of researchers support this kind of approach to work and points out that significant construction of the motor base can be made possible in primary school pupils, where later motor sports will be developed comprehensively (Malacko \& Rađo, 2004; Milanović, 2007; Tonić, Petković, Dragić, Ilić, \& Tankuseva, 2012). The results showed that the participants of the EG included in the exercise model of the artistic gymnastics program, statistically significantly differed $(\mathrm{Q}=.000)$ to the increased level of physical fitness compared to the $\mathrm{CG}$, covered only by the program content of regular physical education classes.

It can be assumed that the differences were due to the applied exercises of the teaching model of the program of artistic gymnastics in the experimental period, which had multiple effects in the EG on the development of the physical fitness of adolescents.

Performing numerous and varied exercises on the spring board has a positive impact on changes in abilities and traits as it contributes to coordination in a better performance of dynamic and static movements and the possibility of matching the action between the force of gravity, on the one hand, and the muscular force on the other; spatial and temporal orientation in the performance of simple and complex structures of motor movements; muscular flexibility of the entire body, as well as other motor abilities and maximal increase in radius in all joint systems (Paunović et al., 2017). 
A large number of studies proved that participants of different ages under the influence of training on the spring board, achieve quantitatively higher values of motor abilities and technical knowledge at the final measurement. Exercises on the spring board enable the force of gravity to act on the longest path, thus achieving greater acceleration and higher peripheral velocity, so that the final effect is the creation of the maximum amount of potential, that is, kinetic energy (Hošek-Momirović, 1978; Babijak, 1981; Petković, Veličković, Petković, Ilić, \& Mekić, 2013; Aleksić \& Mekić, 2010; Mišigoj-Duraković, 2007).

The results of some studies have shown statistically significant differences between male and female gymnasts $(\mathrm{p}<0.001)$ at the height of the jump and relative and maximum strength. Gymnasts that are strong enough can perform certain gymnastic elements qualitatively or compensate for the lack of the height of the bounce by transversal movement (Aleksić-Veljković, Veličković, Sands, Đurović, \& Trajković, 2016).

According to the research of some authors (Madić et al., 2018), training of the developmental gymnastic process was defined, consisting of work on cells, circular work and overcoming obstacles twice a week. A group of participants who trained according to the development gymnastics program showed significant improvements in almost all analyzed parameters compared to pre-program values, with a percentage change and effect size (ES).

Managing the transformation process in spring board exercises is effective if there is feedback, which ensures the exchange of information from teachers to students and vice versa. In order to do this, it is necessary for the teacher to have information on the state of the abilities and qualities with which students exercise to determine the most optimal contents, loads and forms of work and performs constant control of the exercise process. Due to the proven correlation between anthropological features on the one hand and the technique of moving in the spring board exercises on the other, it is necessary to start early with the development of coordination and muscular strength of the body, which at the same time allows for good individual results in later years. The application of various methods and contents of training to increase the success of co-ordination and training exercises in the teaching physical education and certain types of sports is possible only on the basis of the development of basic motor skills and physical fitness (Hošek, 1976; Malacko, 2002; Ilić, 2015).

In adolescents, exercise is an effective way to increase energy needs, to reduce the amount of body fat and to retain the metabolic active tissue. The most common type of training is strength training or resistance training, and this type of training primarily affects the improvement of muscle fitness with slight changes in other fitness components (Pantelić et al., 2014).

Most muscular fitness reductions occur due to a selective muscular atrophy. Muscle tomography has shown that muscle tone decreases over the years and intra-muscle fat increases if the level of muscular fitness is not maintained by regular exercise (Jorgić, Pantelić, Milanović, \& Kostić, 2011).

Improving muscle fitness will cause better balance, agility and speed (Jackson, 2000). Today, the dominant exercises are of a combined type (concurrent training), which in parallel contain durability and strength exercises so that the effect of exercise is effective on all fitness components. In accordance with the curriculum for elementary schools, the contents of the gymnastic program can be adequately influenced by adolescent fitness components (Marušić, 1994; Chan, Hong, \& Robinson, 2001; Kovač, 2012).

The low level of fitness components is a greater indicator of the risk of mortality than obesity or hypertension (Khan et al., 2012). 


\section{CONCLUSION}

From a practical and theoretical point of view, the results of this research can contribute in the pedagogical sense to the educational work of teachers in the field of physical education and sports, as a basis for complementing the program of work that would be applied in the teaching of physical education of elementary school students. The research was carried out with the aim of determining the effects of an exercise program on the spring board on the motor sports of adolescents. The conducted research confirmed that the training program on the spring board, applied at the main stage of physical education, caused the expected adaptive changes in the physical fitness of adolescents.

\section{REFERENCES}

Aleksić-Veljković, A., Veličković, S., Sands, W.A., Đurović, D., \& Trajković, N. (2016). Explosive power in gymnasts: Is there any scientific basis for gender differences? Facta Universitatis Series Physical Education and Sport, 14(1), 121-126.

Aleksić, D., \& Mekić, B. (2010). Efekti primene elemenata sportske gimnastike na razvoj funkcionalnih sposobnosti kod učenica mlađeg školskog uzrasta (Effects of the use of elements of artistic gymnastics on the development of functional abilities in pupils of the younger school age). Sport Mont, 21-22/VII, 192198. In Serbian

Babijak, J.(1981). Relacija između motoričkih sposobnosti i uspeha u sportskoj gimnastici (The relation between motor skills and success in artistic gymnastics). Fizička kultura, 5, 548-466. In Serbian

Broomfied, L. (2011). Complete guide to primary gymnastics. Windsor: Human Kinetics.

Chan, S., Hong, Y., \& Robinson, P. (2001). Flexibility and passive resistance of the hamstrings of young adults using two different static stretching protocols, Scandinavian Journal of Medicine \& Science in Sports, 11(2), 81-86.

Findak, V. (1999). Metodika tjelesne i zdravstvene kulture (Methodology of physical and health culture). Zagreb: Školska knjiga. In Croatian

Fox, K.R. (1994). Research perspectives on children's competence and achivement in physical education and sport. British Journal of Physical Education, 25, 20-22.

Hošek, A. (1976). Struktura koordinacije (Coordination structure). Kineziologija, 6 (1-2), 72-78. In Croatian

Hošek-Momirović, A. (1978). Povezanost morfoloških taksona sa manifestnim i latentnim dimenzijama koordinacije. (Connection of morphological taxons with manifest and latent coordinate dimensions). Doctoral dissertation, Zagreb: Faculty of physical Culture, University of Zagreb. In Croatian

Ilić, D. (1991). Relacije morfoloških i motoričkih karakteristika učenika osmih razreda OŠ $i$ rezultata usvojenosti nastavne građe pedagoških ciklusa (Relation of morphological and motor characteristics of pupils of the eight grades of primary school and results of the adoption of teaching materials of pedagogical cycle). Master's thesis, Belgrade: Faculty of Physical Culture, University of Niš. In Serbian

Ilić, H.S. (2015). Efekti eksplozivne snage na adaptivne procese motoričkih sposobnosti dece uključene u školu gimnastike (The effects of explosive power on the adaptive processes of motor skills of children included in the gymnastics school). Sport and Health, 10, 24-29.

Ilić, H.S.,Popović Ilić, T., Ilić, I., Petković, E., \& Mekić, H. (2014). The effects of the additional work programme in gimnastics in regular physical education class on some motor abilities. Activities in Physical Education and Sport, 4(2), 135-138.

Jackson, J. A. (2000). Fitness testing: Student and teacher perspectives. Journal of Health. Physical Education, Recreation \& Dance, 3(3), 29-31.

Jorgić, B., Pantelić, S., Milanović, Z., \& Kostić, R. (2011). The effects of physical exercise on the body composition of the elderly: A Systematic Review. Facta Universitatis Series Physical Education and Sport, 9(4), 439-453.

Khan, K.M., Thompson, A.M., Blair, S.N., Sallis, J.F., Powell, K.E., et al. (2012). Sport and exercise as contributors to the health of nations. The Lancet, 380(9836), 59-64.

Kimmel, D.C., \& Weiner, I.W. (1995). Adolescence - A Developmental transition. New York: John Wiley \& Sons, Inc. 
Kovač, M. (2012). Assessment of gymnastic skills at physical education - the case of backward roll. Science of Gymnastics Journal, 4(3), 25-35.

Krsmanović, B. (2000). Metodika fizičkog vaspitanja (Methods of physical education). Novi Sad: Faculty of Physical Culture, University of Novi Sad. In Serbian

Kurelić, N., Momirović, K., Stojanović, M., Radojević, Ž. \& Viskić-Štalec, N. (1975). Struktura i razvoj morfoloških i motoričkih dimenzija omladine (Structure and development of morphological and motoric dimensions of youth). Belgrade: Faculty of Physical Education, University of Belgrade. In Serbian

Madić, D., Cvetković, M., Popović, B., Marinković, D., Radanović, D., \& Trajković, N. (2018). Effects of developmental gymnastics on Physical fitness in preschool girls. Facta Universitatis Series Physical Education and Sport, 16(1), 11-18.

Malacko, J. (2002). Sportski trening (Sports training). Novi Sad: Faculty of Sport and Physical Education, University of Novi Sad. In Serbian

Malacko, J., \& Rađa, I. (2004). Tehnologija sporta i sportskog treninga (Technology of sports and sports training). Novi Sad: Faculty of Sport and Physical Education, University of Novi Sad. In Serbian

Marušić, R. (1994). Uticaj izborne nastave fizičkog vaspitanja sa akcentom na sportsku gimnastiku na neke pokazatelje antropološkog statusa učenika osnovnih škola (The influence of elective teaching of physical education with the emphasis on artistic gymnastics on some indicators of the anthropological status of students of elementary schools). Unpublished doctoral dissertation, Belgrade: Faculty of Physical Culture, University of Belgrade. In Serbian

Milanović, D. (2007): Teorija treninga, Priručnik za studente sveučilišnog studija (Training theory, Handbook for students of university studies). Zagreb: Faculty of Kinesiology, University of Zagreb. In Croatian

Mišogoj-Duraković, M. (2008). Kinantropologija (Kinantropology). Zagreb: Kineziološki fakultet Sveučilišta u Zagrebu. In Croatian

Official Gazette of the Republic of Serbia (2017). Pravilnik o izmenama i dopunama Pravilnika o nastavnom planu za drugi ciklus osnovnog obrazovanja $i$ vaspitanja i nastavnom programu za peti razred osnovnog obrazovanja $i$ vaspitanja (Rulebook on Amendments to the Rulebook on the Curriculum for the Second Cycle of Primary Education and curriculum for the fifth grade of elementary education and upbringing), 72/09, 52/11, 55/13, 35/15. In Serbian

Ortega, F.B., Ruiz, J. R., Castillo, M. J., \& Sjostrom, M. (2008). Physical fitness in childhood and adolescence: a powerful marker of health. International Journal of Obesity, 32, 1-11

Pantelić, S., Kostić, R., Popović, R., Aleksandrović, M., Uzunović, S., Milanović, Z., et al. (2014). Fizička aktivnost i fitnes komponente starih osoba (Physical activity and fitness components of the elderly). Niš: Faculty of Sport and Physical Education, University of Niš. In Serbian

Paunović, M., Veličković, S., \& Vukašinović, V., (2017). Systematization of previous research on exercises on the high bar. Facta Universitatis, Series: Physical Education and Sport, 15(2), 309-320.

Petković, D., Veličković, S., Petković, E., Ilić, H.S., \& Mekić, H. (2013). Sportska gimnastika - I, teorija sportske gimnastike (Artistic gymnastics - I, Theory of artistic gymnastics). Niš: Faculty of Sport and Physical Education, University of Niš. In Serbian

Tonić, M., Petković, E., Dragić, B., Ilic, H.S., \& Tankuseva, N. (2012). The differences in the biomechanical characteristics of the Drop jump from an elastic surface in women. Facta Universitatis, Series: Physical Education and Sport, 10(1), 75-79.

Veličković, S., Kolar, E., Kugovnik, O., Petković, D., Petković, E., Bubanj, S., et al. (2011). The kinematic model of the basket to handstand on the parallel bars. Facta Universitatis Series Physical Education and Sport, 9(1), 55-68.

Višnjić, D. (2006). Nastava fizičkog vaspitanja od V do VIII razreda osnovne škole: priručnik za studente, nastavnike i profesore (Teaching of physical education: from V to VIII grade of elementary school: a manual for students, teachers and professors). Belgrade: Zavod za udžbenike. In Serbian

Vranješević, J. (2001). Promena slike o sebi: autoportret adolescencije (Changing the self image: self-portrait of adolescence). Belgrade: Zadužbina Andrejević. In Serbian

Zatsiorsky, V.M. (1975). Fizička svojstva sportiste (Physical characteristics of athletes). Belgrade: NIP „Partizan“. In Serbian

Zrnzević, N. (2007). Transformacija morfoloških karakteristika, funkcionalnih imotoričkih sposobnosti učenika (Transformation of morphological characteristics, functional immortal abilities of pupils). Unpublished doctoral dissertation, Niš: Faculty of Sport and Physical Education, University of Niš. In Serbian 


\section{EFEKTI PROGRAMA SPORTSKE GIMNASTIKE NA FIZIČKI FITNES ADOLESCENATA}

Cilj istraživanja je utvrđivanje efekata programa sportske gimnastike na motorički fitnes adolescenata. Uzorak ispitanika činilo je 28 ispitanika, muškog pola, uzrasta 14 godina \pm 6 meseci, sedmog razreda osnovne škole „Bubanjski Heroji“ u Nišu. Uzorak je bio podeljen na dva subuzorka. Prvi subuzorak činilo je 14 ispitanika koji su tokom eksperimentalnog perioda u glavnoj fazi časa fizičkog vaspitanja realizovali program sportske gimnastike, deset nedelja po dva časa u trajanju od po 45 minuta. Drugi subuzorak kontrolne grupe činila su 14 ispitanika koji su tokom eksperimentalnog perioda u glavnoj fazi časa fizičkog vaspitanja realizovali programske sadržaje redovne nastave fizičkog vaspitanja. Uzorak motoričkih mernih instrumenata činile su tri varijable eksplozivne snage (skok udalj iz mesta, troskok iz mesta i vertikalni skok) i tri varijable sprinterskog trčanja (trčanje $20 m$ visokim startom, trčanje $30 \mathrm{~m}$ visokim startom i trčanje $50 \mathrm{~m}$ visokim startom). Primenjen je program ,Statistica “ 8.0 for Windows, za izračunavanje osnovne statistike, kanoničke diskriminativne analize i multivarijantne analize kovarijanse. Rezultati istraživanja su pokazali da postoje statistički značajni efekti primene vežbi programa sportske gimnastike, u glavnom delu časa fizičkog vaspitanja, na motorički fitnes adolescenta eksperimentalne grupe na kraju eksperimentalnog perioda.

Ključne reči: sportska gimnastika, nastava, motorički fitnes, adolescenti 